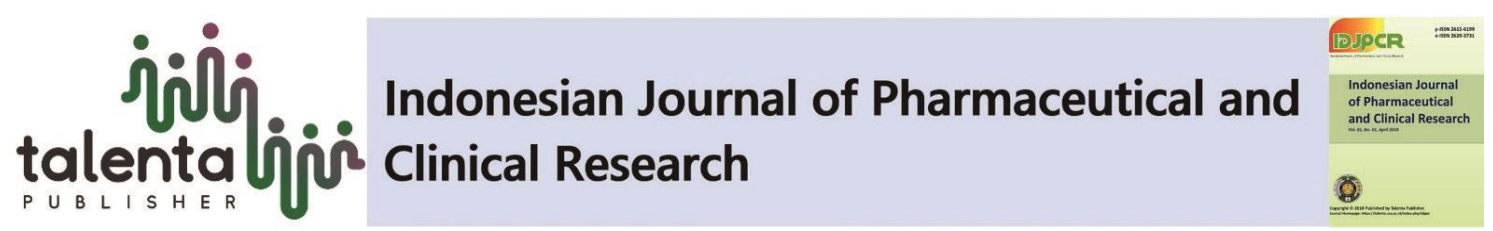

\title{
Formulation and Evaluation of Skin Anti-aging Nanocream Containing Canola (Brassica napus L.) Oil
}

\author{
Sumaiyah, Sumaiyah" and Meyliana \\ Department of Pharmaceutical Technology, Faculty of Pharmacy, Universitas Sumatera Utara, Medan \\ Indonesia
}

\begin{abstract}
Canola (Brassica napus L.) oil high in vitamin E is good for skin care. Vitamin $\mathrm{E}$ is an effective antioxidant that protects our skin from free radical damage and keeps the skin elasticity, evenness, reduces blemishes, acne scars, and slows down the skin's aging. This study aimed to formulate canola oil nano cream and find out canola oil nano cream gives a higher anti-aging effect than canola oil cream. Nanocream as anti-aging formulated in four variations of canola oil concentration $2,5 \%, 5 \%, 7,5 \%$ and $10 \%$. Nanocream was tested $\mathrm{IC}_{50}$, and observed the characteristics and stability. Then, continue to irritation test and anti-aging activity of nanocream compared with cream on the skin of volunteers. The result showed that nanocream of variation canola oil was in a different color and distinctive smell. The preparation was stable in 12 weeks room temperature storage, homogenous, and no phase separation. Particle size was $5882.17 \mathrm{~nm}, 348.47 \mathrm{~nm}, 321.16 \mathrm{~nm}, 318.16 \mathrm{~nm}$ initially and increased after 12 weeks. There was no irritation, and anti-aging activity was higher than cream. Canola oil can be formulated as nanocream, stable in 12 weeks storage, and nano cream has higher anti-aging activity than cream.
\end{abstract}

Keyword: canola oil, nanocream, cream, anti-aging

Abstrak. Minyak kanola (Brassica napus L.) tinggi vitamin E bagus untuk perawatan kulit. Vitamin E adalah antioksidan efektif yang melindungi kulit kita dari kerusakan akibat radikal bebas dan menjaga elastisitas kulit, kerataan, mengurangi noda, bekas jerawat, dan memperlambat penuaan kulit. Penelitian ini bertujuan untuk merumuskan nanokrim canola oil dan mengetahui nanokrim canola oil memberikan efek anti penuaan yang lebih tinggi dibandingkan krim minyak canola. Nanokrim sebagai anti aging diformulasikan dalam empat variasi konsentrasi minyak canola yaitu 2,5\%, 5\%, 7,5\% dan 10\%. N anokrim diuji $I_{50}$, diamati karakteristik, stabilitas, dan daya sebarnya. Kemudian dilakukan uji iritasi dan aktivitas anti-aging nanokrim dibandingkan dengan krim pada kulit sukarelawan. Hasil penelitian menunjukkan bahwa nanokrim dari variasi minyak canola memiliki warna dan bau yang berbeda. Stabil dalam penyimpanan suhu ruang 12 minggu, homogen, tipe emulsi minyak/air, tidak ada pemisahan fasa. Tegangan permukaan 36,041,4 dyne/cm. Ukuran partikel 5882,17 nm, 348,47 nm, 321,16 nm, 318,16 nm pada awalnya dan meningkat setelah 12 minggu. Tidak ada iritasi, dan aktivitas anti-penuaan lebih tinggi dari krim. Minyak canola dapat diformulasikan sebagai nanokrim, stabil dalam penyimpanan 12 minggu, dan nanokrim memiliki aktivitas anti penuaan yang lebih tinggi daripada krim.

Kata Kunci: minyak canola, nanokrim, krim, anti-penuaan

*Corresponding author at: Jl. Tri Dharma No. 5, Fakultas Farmasi, Universitas Sumatera Utara, Medan, Indonesia

E-mail address: sumaiyah@usu.ac.id 
Received 13 January 2021 | Revised 18 May 2021 | Accepted 10 May 2021

\section{Introduction}

An organism grows old because of the accumulated damage by free radicals in the cells over time. Free radicals are highly reactive free molecules that steal electrons from paired electrons in neighboring molecules, thus creating other free radicals. Oxygen is a potent producer of free radicals known as reactive oxygen species (ROS). ROS attacks the cell membrane structures, causing spots on the skin. The free radical attack eventually leads to wrinkles, sagging skin, and age spots [1].

Canola (Brassica napus L.) oil has high vitamin E, which is useful for skin care. Vitamin E is an antioxidant that effectively protects the skin from damage caused by free radicals and can also maintain flexibility, smoothness and reduce acne scars and slow down wrinkles on the skin. The fatty acids contained in canola oil are oleic acid (61\%), linoleic acid (21\%), stearic acid (2\%), alpha-linoleic acid (10\%), palmitic acid (4\%) [2].

The test of free radical scavenging power in vegetable oil was carried out with DPPH. The antioxidant effect was demonstrated in the loss of purple color to DPPH in the samples tested. The smaller the $\mathrm{IC}_{50}$ (Inhibitory Concentration 50) value indicates a higher DPPH radical scavenging activity. Canola oil has a high free radical scavenging activity after sunflower and safflower oil [3].

Nanocream is one of several delivery system technology innovations in cosmetic products. Nanocream is a semisolid preparation, which is a stable emulsion and has a diameter of about 20-500 $\mathrm{nm}$. Nanocream preparations are easier to use and spread over the skin area easily and comfortably. Another advantage of nanocream as topical preparations is that they increase the absorption of active substances in the skin. So that, people prefer cosmetic products in cream dosage forms rather than other cosmetic dosage forms [4].

Nanocream technology with active ingredients of canola oil has not yet been found on the market. This nanotechnology will also support active ingredients' penetration through the skin layers due to the small droplet size. Therefore, the authors were interested in formulating and evaluating canola oil as a nanocream preparation as an anti-aging. 


\section{Methods}

\subsection{Materials}

The materials used in this study were canola oil (Mazola), DPPH, ethanol 96\%, Tween 80, propylene glycol, cetyl alcohol, methyl paraben, propyl paraben, TEA, stearic acid, glycerin and distilled water.

\subsection{Formulation of Canola Oil Nanocream}

The percentage composition of ingredients in nanocream is modified from the nanocream formula that has been carried out in previous research [4] on the manufacture of nanocreams using POEs oil (palm oil esters), Tween 80 surfactant and span 20 cosurfactant. The composition of the ingredients used in this study can be seen in Table 1.

Table 1. Formulation of Canola Oil Nanocream

\begin{tabular}{lcccc}
\hline \multicolumn{1}{c}{ Materials } & $\mathbf{F 1}(\boldsymbol{\%} \mathbf{b} / \mathbf{b})$ & $\mathbf{F 2}(\boldsymbol{\%} \mathbf{b} / \mathbf{b})$ & $\mathbf{F 3}(\boldsymbol{\%} \mathbf{b} / \mathbf{b})$ & $\mathbf{F 4}(\boldsymbol{\%} \mathbf{b} / \mathbf{b})$ \\
\hline Canola oil & 2.5 & 5 & 7,5 & 10 \\
Tween 80 & 36 & 36 & 36 & 36 \\
Propylene glycol & 6 & 6 & 6 & 6 \\
Cethyl alcohol & 0.6 & 0.6 & 0.6 & 0.6 \\
Methylparaben & 0.1 & 0.1 & 0.1 & 0.1 \\
Propylparaben & 0.05 & 0.05 & 0.05 & 0.05 \\
Distilled water ad & 100 & 100 & 100 & 100 \\
\hline
\end{tabular}

Note:

F1: $2.5 \%$ canola oil nanocream

F2: $5 \%$ canola oil nanocream

F3: $7.5 \%$ canola oil nanocream

F4: $10 \%$ canola oil nanocream

\subsection{Preparation of Canola Oil Nanocream}

Canola oil nanocream preparations were made using a high-energy emulsification method (high-shear stirring) using a mixer [5]. The oil phase is cetyl alcohol mixed with canola oil, then stirred using a hotplate stirrer at $350 \mathrm{rpm}, 55^{\circ} \mathrm{C}$ for 30 minutes. The water phase in the form of methyl paraben and propyl paraben is dissolved in the remaining distilled water, then heated on a hotplate until completely dissolved, then the solution is cooled. Next, Tween 80 and propylene glycol were mixed into a solution of methylparaben and propylparaben. Then stirred with a magnetic stirrer at $350 \mathrm{rpm}$ for 30 minutes. The water phase is poured gradually into the oil phase, then the mixture is stirred with a magnetic stirrer at a speed of $2000-3000 \mathrm{rpm}$ for 8 hours until formed a thick emulsion. Then homogenized with a mixer for 30 minutes. Add a few drops of rose scented perfume, then mix it using a mixer to form a homogeneous cream mass. 


\subsection{Preparation of Canola Oil Cream}

The oil phase in the form of stearic acid (14\%) and cetyl alcohol $(0.2 \%)$ is melted over a water bath and poured into a hot mortar. Then mixed with $10 \%$ canola oil in a hot mortar, and stirred homogeneously. Water phase: methylparaben $(0.1 \%)$, glycerin $(10 \%)$, TEA $(1 \%)$ dissolved in the remaining distilled water. Then heated on a water bath until it dissolves completely, then cooled. The water phase is poured gradually into the oil phase in the hot mortar. Mixed until a homogeneous cream mass form. Add a few drops of rose scented perfume and stir homogeneously.

\subsection{Antioxidant Activity Testing}

Determination of antioxidant activity using the DPPH method begins with sampling $0.1 \mathrm{~mL}$ plus $3 \mathrm{~mL}$ of $0.004 \%$ DPPH radical solution in $95 \%$ ethanol and then vortexing the solution to make it homogeneous. They were incubated in a dark room and at room temperature for 30 minutes. The absorbance is measured at a wavelength of $520 \mathrm{~nm}$. Ethanol $96 \%$ was used for standards. The antioxidant activity was calculated by reducing the absorbance of the control by absorbing the sample and dividing it (control absorbance x 100\%) [6].

\subsection{Observation of Physical Stability of Preparations}

Each canola oil nanocream and cream preparation was placed in a glass container and stored at two different temperatures separately. Namely, in the climatic chamber at a temperature of 40 ${ }^{\circ} \mathrm{C} \pm 2{ }^{\circ} \mathrm{C}$ and $\mathrm{RH} 75 \% \pm 5 \%$ for four weeks and at room temperature for 12 weeks. Each formula was subjected to visual observations of color, odor, shape, and phase separation with observations once a week [7], [8].

\subsection{Cycling Test}

Samples were stored at $4^{\circ} \mathrm{C}$ for 24 hours, then transferred to an oven at $40^{\circ} \pm 2^{\circ} \mathrm{C}$ for 24 hours (one cycle). The test was carried out in 6 cycles, then the physical changes that occurred (were there any separation) were observed [9].

\subsection{Homogeneity Examination}

A certain number of preparations, when applied to a piece of glass or other suitable transparent material, the preparation must show a homogeneous composition and no visible coarse grains [10].

\subsection{Determination of the Type of Preparation Emulsion}

Determination of the type of emulsion for the preparation was carried out by gradually adding methylene blue to the preparation, and if it dissolves when stirred, then the emulsion is a type of oil in water [11].

\subsection{Preparation pH measurement}

The $\mathrm{pH}$ of the preparations was determined using a $\mathrm{pH}$ meter. The $\mathrm{pH}$ determination was carried out after manufacturing for $0,1,2,3,4$ weeks at room temperature. 


\subsection{Viscosity Determination}

Viscosity measurement was carried out by placing the preparation in a $100 \mathrm{ml}$ beaker glass and selecting the appropriate spindle number. This measurement was carried out in three repetitions using a Brookfield DV-E viscometer [12]. Determination of canola oil nanocream preparations' viscosity was carried out before and after storage for $0,1,2,3,4$ weeks at room temperature.

\subsection{Centrifugation Test}

The centrifugation test is carried out at the beginning after the preparation is made by measuring one time. The preparation was put into a centrifugation tube then centrifuged at $3750 \mathrm{rpm}$ for 5 hours [13].

\subsection{Determination of Nanocream Particle Size}

Determination of the particle size of the nanocream using the FRITSCH Analyzer 2.2 particle size analyzer. The tool's working principle is to use Laser Diffraction (LAS), which is when the particles pass through the laser beam and the light is scattered by the particles being collected over the range of angles facing directly. A computer will analyze this scattered intensity distribution as a particle size distribution [14].

\subsection{Volunteer Irritation Test}

Cosmetics are applied behind the ear, then left for 24 hours, and see the changes in the form of redness, itching, and roughness of the skin [15].

\subsection{Testing of Anti-Aging Activity}

The test for the anti-aging activity of cream and nanocream preparations used 12 volunteers and divided into two groups, namely:

- Group I: 6 volunteers for nanocream F4 (10\% canola oil)

- Group II: 6 volunteers for cream (10\% canola oil)

All volunteers' initial skin conditions were measured, including moisture content, pore size, spots, and wrinkles, using a skin analyzer according to the measurement parameters. Changes in skin condition were measured every week for four weeks using a skin analyzer.

\subsection{Data Analysis}

The research data were analyzed using the SPSS (Statistical Product and Service Solution) program 17. The first step was to test the data for normality. Then proceed with the Mann Whitney test to see the real difference between treatments.

\section{Results and Discussion}

\subsection{Canola Oil Nanocream}

Canola oil is an oil that is rich in vitamin E, including antioxidants and is useful for keeping skin feeling soft and caring for the skin. In addition, the fatty acids contained in it are useful for preventing and treating dry skin [16]. Apart from its high vitamin E content, canola oil also 
contains fatty acids. The highest fatty acid in canola oil is oleic acid, namely $56-62 \%$. Based on the canola oil analysis certificate issued by the Indonesian Oil Palm Research Institute (certificate number 54/01 / sert / I 2015), the content of vitamin E and fatty acids (oleic acid) in the oil is $125.60 \mathrm{ppm}$ and $59.1 \%$, respectively.

Canola oil nanocream preparations were prepared by emulsification method high energy (highshear stirring) using a mixer [5]. The mixer is included in the stator rotor system or emulsification method with high speed stirring. The particle reduction mechanism by the mixer uses the centripetal force generated by the rotating rotor at high speed. This centripetal force causes the emulsion to be attracted into the rotor system and thrown into the space between the rotor and the inner wall of the stator, causing intense emulsification. The presence of bulkheads on the rotor legs forces the droplets to form a smaller size [5], [17].

Nanocream containing canola oil was made with variations in oil concentration, namely $2.5 \%$, $5 \%, 7.5 \%$, and $10 \%$. The resulting color is transparent yellow, yellowish-white, white, and had a distinctive smell (Fig. 1)

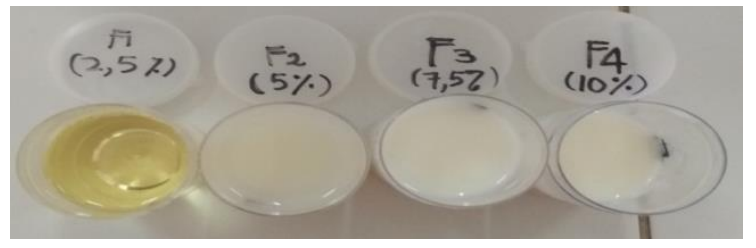

Figure 1. Nanocream variety concentration of canola oil 2.5\%, 5\%, 7.5\% and 10\%.

\subsection{Canola Oil Cream}

Cream preparations containing $10 \%$ canola oil were made by the cream base ingredient and the addition of $10 \%$ canola oil. The resulting preparation is in the form of a white cream, slightly solid, and has a distinctive smell. The results of the cream formulation with a concentration of $10 \%$ canola oil can be seen in Figure 2.

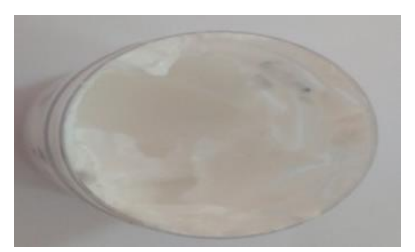

Figure 2. The cream concentration of canola oil $10 \%$.

\subsection{Antioxidant Activity of Canola Oil}

In testing the antioxidant activity of canola oil at a wavelength of $516.5 \mathrm{~nm}$ using the DPPH method, it resulted in an $\mathrm{IC}_{50}$ of $1.456 \mu \mathrm{g} / \mathrm{ml}$. Meanwhile, based on the literature, vitamin E which is used as a comparison, has an $\mathrm{IC}_{50}$ of $2.146 \mu \mathrm{g} / \mathrm{mL}$. The $\mathrm{IC}_{50}$ value of a less than 50 $\mu \mathrm{g} / \mathrm{mL}$ compound can be categorized as a very strong antioxidant [18]. 


\subsection{Physical Stability of Preparations}

Nanocream and cream stored in a climatic chamber at $40{ }^{\circ} \mathrm{C} \pm 2{ }^{\circ} \mathrm{C}$ and $75 \% \pm 5 \% \mathrm{RH}$ for four weeks and room temperature for 12 weeks showed stable physical properties of nanocream. The stability can be seen from the absence of phase separation, color, or odor changes. However, we can see a color change (turn yellow) and smell (turn rancid) on the cream preparations (Table 2).

Table 2. The Stability of Canola Oil Nanocream and Cream

\begin{tabular}{cll}
\hline \multirow{2}{*}{ Storage } & \multicolumn{2}{c}{ Physic Stability } \\
\cline { 2 - 3 } & Nanocream & Cream \\
\hline $\begin{array}{c}\text { 4 weeks in Climatic } \\
\text { Chamber }\end{array}$ & Stable & $\begin{array}{l}\text { Color changing (into yellow) } \\
\text { Odor changing (rancid) }\end{array}$ \\
\hline $\begin{array}{c}12 \text { weeks in room } \\
\text { temperature }\end{array}$ & Stable & Stable \\
\hline
\end{tabular}

Cycling test results after 6 cycles, nanocream did not show any changes, both shape, color, odor. Likewise, the cream preparations did not show changes in shape, change in color and odor. In this test, neither the nanocream nor the cream showed any phase separation.

The homogeneity test results on nanocream and canola oil cream preparations showed that there were no coarse grains of all the preparations tested on a transparent glass or other suitable material respectively. This means that the preparations made have a homogeneous arrangement [10].

Determination of the emulsion type of the preparation is carried out by gradually adding methylene blue to the preparation, if it dissolves when stirred, then the emulsion is of the type of oil in water. If the water is the outer phase $(\mathrm{o} / \mathrm{w})$, the dye will dissolve in it and diffuse evenly throughout the water. If the emulsion is of type w/o, the dye particles will stay clustered on the surface [19]. Result of type determination emulsion for canola oil nanocrim preparations indicated that the emulsion type for nanocreams preparation was o/w type.

The $\mathrm{pH}$ of nanocreams and creams is in the range 5.7-6.3. For 4 weeks, the $\mathrm{pH}$ of the preparation decreased, but it was still in accordance with the $\mathrm{pH}$ of the skin namely in the range of 4.5-6.5 so it is still safe to use and does not cause irritation to the skin [20].

Viscosity is a statement of the resistance of a liquid to flow. The higher the viscosity value, the greater the resistance [19]. The data from the viscosity test of canola oil and nanocream cream can be seen in Table 3 . 
Table 3. Viscosity of canola oil nanocream and cream

\begin{tabular}{cccccc}
\hline Formula & \multicolumn{5}{c}{ Viscosity (cP) } \\
\cline { 2 - 5 } & Week 0 & Week 1 & Week 2 & Week 3 & Week 4 \\
\hline F1 & 350 & 350 & 400 & 450 & 480 \\
F2 & 2200 & 2250 & 2250 & 2300 & 2350 \\
F3 & 6400 & 6400 & 6450 & 6500 & 6600 \\
F4 & 9500 & 9550 & 9600 & 9680 & 9700 \\
Cream & 16500 & 16250 & 15900 & 15750 & 15500 \\
\hline
\end{tabular}

The viscosity of the nanocreams showed an increase in the viscosity value for 4 weeks of storage at room temperature. Within other words, over time the nanocream preparations became thicker. On the other hand, the cream preparations experienced a decrease in viscosity or over time the cream became thinner.

\section{Particle Size of Canola Oil Nanocream}

Nanocream particle measurement aims to determine the size particles of each of the canola oil nanocream formulas for 12 weeks at room temperature storage. Particle measurements were carried out using the FRITSCH Analyzer 2.2 Nanotech. The particle size data of canola oil nanocreams with concentrations of $2.5 \%, 5 \%, 7.5 \%$, and $10 \%$ can be seen in Table 4 .

Table 4. Mean of particle size of canola oil nanocream

\begin{tabular}{ccccc}
\hline $\begin{array}{c}\text { Storage time } \\
\text { (Week) }\end{array}$ & F1 & F2 & F3 & F4 \\
\cline { 2 - 5 } & 5882.17 & 348.47 & 321.16 & 318.16 \\
\hline 0 & 7708.81 & 364.27 & 344.79 & 321.16 \\
2 & 11856.11 & 397.25 & 377.56 & 338.36 \\
4 & 13416.30 & 491.57 & 394.70 & 339.86 \\
8 & 15561 & 518.23 & 485.40 & 391.89 \\
\hline
\end{tabular}

Based on Table 4, nanocream with canola oil concentrations of $2.5 \%, 5 \%, 7.5 \%$, and $10 \%$ indicate that the preparation experienced an increase in the average particle size during storage for 12 weeks at room temperature. However, the increase in F2, F3, and F4's average particle size is still within the nanocream requirement range of 20-500 $\mathrm{nm}$ [4]. The method used in the manufacture of nanocreams with a canola oil concentration of $2.5 \%, 5 \%, 7.5 \%$, and $10 \%$ is a 
high energy emulsification method, namely a high-shear stirring, namely a mixer. The decrease in mean particle size occurred with stirring intensity [5].

From the results of particle measurements, it can be seen that the higher the canola oil concentration, the smaller the resulting particle size and vice versa. This happens because the higher the oil concentration, the more particles will collide with each other during high energy stirring with a mixer. The amount of canola oil has the opposite effect of particle size. The optimum or appropriate amount of surfactants also affects the particle size [12], [21].

\section{Results of the Irritation Test on Volunteers}

The irritation test for nanocream and cream preparations was carried out on 12 people volunteer according to the specified requirements. The preparation was applied to the volunteers' back ear and left for 24 hours. The preparations that were applied to volunteers were nanocream with $10 \%$ canola oil concentration (6 volunteers) and cream with $10 \%$ canola oil concentration (6 volunteers). Nanocreams and creams did not show any irritation reaction either primary or secondary irritation, in the form of redness, itching, and skin roughening after 24 hours of attachment. It can be concluded that both the nanocream and cream preparations are safe to use.

\section{Anti-Aging Activity of Canola Oil Nanocream}

After using nanocream in volunteers for 4 weeks, the anti-aging activity increased from dehydration to normal with a\% recovery of $26.5 \pm 2.4 \%$ (Table 5). Meanwhile, the use of cream on the volunteers increased the water content from dehydration to normal with\% recovery of $20.4 \pm 3.2 \%$. The fatty acids contained in canola oil can prevent and treat dry skin [16]. Apart from treating dry skin. canola oil can also keep skin moist. The highest fatty acid contained in canola oil is oleic acid. Vitamin E acts as a moisturizer that can maintain water bonds in the skin [20], [22]. The lipophilic structure of vitamin E enhances absorption and makes it a cosmetically effective moisturizer. Based on statistical analysis using Mann Whitney, the use of the preparation at week 1 did not give a significant difference $(p>0.05)$ between the nanocream and cream formulas on the pore size on the volunteer's faces. The usage in week 2,3 , and 4 showed a significant difference $(\mathrm{p}<0.05)$ between the canola oil nanocream $(\mathrm{F} 4)$ formula and cream on the skin pores on the volunteers' faces. 
Table 5. Anti-aging activity of canola oil nanocream (F4) and cream

\begin{tabular}{|c|c|c|c|c|c|c|}
\hline \multirow{2}{*}{ Formula } & \multicolumn{6}{|c|}{ Duration of use of the preparation (Week) } \\
\hline & $\mathbf{0}$ & 1 & 2 & 3 & 4 & \% recovery \\
\hline & \multicolumn{6}{|c|}{ Moisture } \\
\hline $\begin{array}{l}\text { F4 (Canola Oil } \\
\text { Nanocream 10\%) }\end{array}$ & $28.7 \pm 1.4$ & $32.2 \pm 1.2 \quad 3$ & $34.8 \pm 1.8 \quad 36$ & $.8 \pm 1.7 \quad 3$ & $39.0 \pm 1.5$ & $26.5 \pm 2.4$ \\
\hline \multirow[t]{2}{*}{ Cream } & $28.5 \pm 1.6$ & $30.7 \pm 1.5 \quad 3$ & $32.8 \pm 1.7 \quad 34$ & $.5 \pm 2.4 \quad 3$ & $35.8 \pm 2.1$ & $20.4 \pm 3.2$ \\
\hline & \multicolumn{6}{|c|}{ Pore } \\
\hline $\begin{array}{l}\text { F4 (Canola Oil } \\
\text { Nanocream 10\%) }\end{array}$ & $41.7 \pm 2.7$ & $34.7 \pm 2.2$ & $2 \quad 28.5 \pm 2.7$ & $24.2 \pm 2.8$ & $8 \quad 19.7 \pm 3.3$ & $53.0 \pm 6.1$ \\
\hline \multirow[t]{2}{*}{ Cream } & $41.0 \pm 4.5$ & $38.5 \pm 4.0$ & $\begin{array}{ll}0 & 36.2 \pm 4.2\end{array}$ & $33.8 \pm 3.9$ & $9 \quad 31.5 \pm 3.6$ & $23.2 \pm 2.3$ \\
\hline & \multicolumn{6}{|c|}{ Spot } \\
\hline $\begin{array}{l}\text { F4 (Canola Oil } \\
\text { Nanocream 10\%) }\end{array}$ & $44.7 \pm 5.1$ & $38.2 \pm 4.3$ & $3 \quad 29.7 \pm 5.6$ & $23.0 \pm 4.4$ & $4 \quad 16.7 \pm 3.3$ & $62.9 \pm 4.1$ \\
\hline \multirow[t]{2}{*}{ Cream } & $44.2 \pm 5.2$ & $39.0 \pm 4.0$ & $0 \quad 34.8 \pm 4.3$ & $30.7 \pm 4.5$ & $5 \quad 25.5 \pm 4.0$ & $42.3 \pm 5.0$ \\
\hline & \multicolumn{6}{|c|}{ Wrinkle } \\
\hline $\begin{array}{l}\text { F4 (Canola Oil } \\
\text { Nanocream 10\%) }\end{array}$ & $44.3 \pm 4.4$ & $40.0 \pm 4.5$ & $5 \quad 29.3 \pm 5.5$ & $22.0 \pm 4.3$ & $3 \quad 17.5 \pm 3.6$ & $60.8 \pm 5.0$ \\
\hline Cream & $45.5 \pm 3.6$ & $43.8 \pm 3.1$ & $1 \quad 41.8 \pm 4.1$ & $40.0 \pm 3.9$ & $9 \quad 37.7 \pm 4.0$ & $17.3 \pm 4.3$ \\
\hline
\end{tabular}

Nanocream preparations reduce blemishes from multiple blemishes to slight blemishes with a\% recovery of $62.9 \pm 4.1 \%$. While the cream reduces blemishes from many blemishes to multiple blemishes with a percent recovery of $42.3 \pm 5.0 \%$. The antioxidant activity found in vitamin $\mathrm{E}$ works to prevent skin aging. Vitamin E will inhibits tyrosinase and melanogenesis in epidermal melanocytes. In addition, vitamin E will stimulate intrcellular glutathione (GSH) synthesis so that it can have a depigmentation effect on skin that has decreased skin pigmentation [23]. Based on statistical analysis using Mann Whitney. the use of preparations on the faces of volunteers at week 1 and 2 did not show a significant difference ( $p>0.05)$. The use of the preparations at week 3 and 4 showed a significant difference $(\mathrm{p}<0.05)$.

The use of nanocreams and creams for 4 weeks can reduce wrinkles on the face, especially at the corners of the eyes. Nanocream preparations reduce the rate of wrinkles from wrinkled to wrinkled with a\% recovery of $60.8 \pm 5.0 \%$. Meanwhile, the cream preparations reduced the level of wrinkles, but only gave a\% recovery of $17.3 \pm 4.3 \%$. Vitamin $\mathrm{E}$ is the most fat soluble antioxidant important for repairing skin that is experiencing aging problems. As a free radical scavenger. vitamin $\mathrm{E}$ inactivates radicals and breaks bonds in harmful reactions. and protects cell membranes. The skin is the first to be exposed to harmful UV rays. Therefore, topical application of preparations containing vitamin E is very important [22]. Based on the results of statistical analysis using Mann Whitney, the use of preparations at week 1 did not show a significant difference ( $p>0.05)$. While the use of preparations at week 2, 3, and 4 showed a significant difference $(\mathrm{p}<0.05)$. 


\section{Conclusion}

Canola oil can be formulated into nanocream preparations with variations in the concentration of canola oil 5\%; 7.5\%; and 10\%. The concentration of Tween 80 as a surfactant was $36 \%$ and the concentration of propylenglycol as a cosurfactant was $6 \%$. The F2 preparations are slightly yellowish white and the F3 and F4 are white. All formula nanocream (F2,F3 and F4) were stable in storage for 12 weeks at room temperature. Nanocream preparations containing canola oil provide higher antiaging activity than cream preparations containing canola oil. This is indicated by a greater \% recovery in nanocreams compared to creams from several aging parameters, namely moisture, pores, spots, and wrinkles.

\section{Acknowledgement}

The authors are grateful to the Faculty of Pharmacy, Universitas Sumatera Utara for facilitating this research.

\section{REFERENCES}

[1]. N. Dayan, Skin aging handbook: an integrated approach to biochemistry and product development, William Andrew Inc. United State of America. pp. 22, 58, 150, 236. 2008.

[2]. A.T. Honary, and E. Richter, Biobased lubricants and greases technolgy and products. Canada: Library Of Congress Cataloging Publication Data. pp. 42-43. 2011.

[3]. T. Xuan, G. Gangqiang, T. Minh, T. Quy, and T. Khanh, "An Overview of Chemical Profiles, Antioxidant and Antimicrobial Activities of Commercial Vegetable Edible Oils Marketed in Japan," Foods, vol. 7, no. 2, p. 21, Feb. 2018.

[4]. M. F. Abdulkarim, S. M. Hameem, G. Z. Abdullah, E. S. Mahdi, M. Chitneni, M. F. Yam, A. Faisal, I. M. Salman, O. Z. Ameer, M. Z. Abdulsattar, M. Basri, and A. M. Noor, "Formulation and characterization of palm oil esters based nano-cream for topical delivery of piroxicam.," International Journal of Drug Delivery, vol. 2, no. 4, pp. 287298, Dec. 2010.

[5]. M. Y. Koroleva and E. V. Yurtov, "Nanoemulsions: the properties, methods of preparation and promising applications," Russian Chemical Reviews, vol. 81, no. 1, pp. 21-43, Jan. 2012.

[6]. E.Y. Yuniwarti, T.R. Saraswati, and E. Kusdiyantini, "Aktivitas antioksidan berbagai minyak edible menggunakan metode DPPH. Buletin Anatomi dan Fisiologi, vol. 3, no.1, pp. 85- 88, 2018.

[7]. A.B. Kananlua, "Preparation of dilpamitate kojic acid nanocrims with a combination of surfactant Tween 80 and propylene glycol using a mixer. Thesis. Faculty of Pharmacy. Universitas Sanata Dharma. Yogyakarta. pp. 40-41. 2016.

[8]. Y. Darwis, N. Zainol, and T. Ming, "Development and characterization of cinnamon leaf oil nanocream for topical application," Indian Journal of Pharmaceutical Sciences, vol. 77, no. 4, p. 422, 2015.

[9]. R. Dewi, E. Anwar, and Y. K. S, "Uji Stabilitas Fisik Formula Krim yang Mengandung Ekstrak Kacang Kedelai (Glycine max)," Pharmaceutical Sciences and Research, vol. 1, no. 3, pp. 194-208, Dec. 2014.

[10]. Directorate general of drug and food control. Pharmacopoeia of Indonesia. $3^{\text {rd }}$ ed. Ministry of Health of the Republic of Indonesia. Jakarta. pp. 649, 659. 1979.

[11]. Directorate general of drug and food control. Indonesian cosmetics formulary. Ministry of Health of the Republic of Indonesia. Jakarta. pp. 29. 1985.

[12]. P.J. Sinko, Pharmaceutical Physics and Pharmaceutical Sciences. EGC. Jakarta. pp. 647648. 2006. 
[13]. L. Lachman, Lieberman, A. Herbert, Kanig, and L. Joseph. Pharmaceutical industry theory and practice 1. $3^{\text {rd }}$ ed. Universitas Indonesia Press. Jakarta. pp. 1081-1083. 1994.

[14]. Y. Triapriani, Preparation of nanocellulose from empty palm fruit bunches by using acid hydrolysis method. Thesis. Faculty of Math and Science. Universitas Lampung. 2016.

[15]. S.M. Wasitaatmadja, Medical cosmetic science guide. UI Press. Jakarta. pp. 111-112. 1997.

[16]. R. Khattab, C. Rempel, M. Suh, and U. Thiyam, "Quality of Canola Oil Obtained by Conventional and Supercritical Fluid Extraction," American Journal of Analytical Chemistry, vol. 03, no. 12, pp. 966-976, 2012.

[17]. S.K. Niazi, Handbook of pharmaceutical manufacturing formulations: semisolid products. CRC Press LLC. Florida. pp. 22-23. 2004.

[18]. N.N. Izzati, Diniatik and S.S. Wiranti,"The antioxidant activity of mangosteen (Garcinia mangostana L.) leaf extract based on the DPPH (2,2Diphenyl-1-phycryl hydrazil) method", Pharmacy Journal, vol. 9, no. 3, pp. 111-119, 2012.

[19]. A.Martin, J. Swarbrick and A. Cammarata, Physical pharmacy: the basics of physical chemistry in pharmaceutical sciences. $3^{\text {rd }}$ ed. UI Press. Jakarta. pp. 1135, 1144. 1993.

[20]. R.I. Tranggono, and F. Latifah, Handbook of cosmetic science. Gramedia Pustaka Utama. Jakarta. pp. 6-8. 2013.

[21]. T. Mehmood, "Optimization of the canola oil based vitamin E nanoemulsions stabilized by food grade mixed surfactants using response surface methodology," Food Chemistry, vol. 183, pp. 1-7, Sep. 2015.

[22]. A. Pappas, Nutrition and skin: lessons for anti-aging, beauty and healthy skin. Springer. London. pp. 49, 59. 2011.

[23]. Z. D. Draelos and L. A. Thaman, Eds., "Cosmetic Formulation of Skin Care Products," Jun. 2005. 